\title{
Analisis Kemampuan Literasi Sains dan Teknologi Guru IPA SMP Negeri dan Swasta Se-Kecamatan Poasia Kota Kendari
}

\author{
Lucky $^{1)} *$, Hunaidah $\mathbf{M}^{2)}$, La Tahang ${ }^{3)}$ \\ 1)* Jurusan Pendidikn Fisika, FKIP ,Universitas Halu Oleo, Kendari, Sulawesi Tenggara \\ 2), 3) Jurusan Pendidikn Fisika, FKIP ,Universitas Halu Oleo, Kendari, Sulawesi Tenggara \\ *Korespondensi Email: lucky@gmail.com
}

\begin{abstract}
Abstrak: Tujuan penelitian ini adalah untuk mendeskripsikan gambaran literasi sains yang dimiliki guru IPA SMP Negeri teknologi yang dimiliki guru IPA SMP Negeri dan Swasta se- Kecamatan Poasia Kota Kendari. Teknik analisis data yang digubakan adalah teknik analisis deskriptif. Berdasakan hasil penelitian kemampuan literasi sains guru IPA SMP Negeri dan Swasta se-Kecamatan Poasia, Kota Kendari secara umum berada pada kategori rendah dengan presentase rata-rata sebesar 56,9\% dengan standard deviasi 12,3\%. Sedangkan kemampuan literasi teknologinya secara umum berada pada kategori cukup dengan presentase rata-rata sebesar $69 \%$ dengan standard deviasi $9 \%$.
\end{abstract}

Kata Kunci: Literasi; Literasi Sains; Literasi Teknologi

Abstract: The purpose of this study was to describe the description of scientific literacy possessed by science teachers at State Junior High Schools technology owned by science teachers at Public and Private SMP in Poasia District, Kendari City. The data analysis technique used is descriptive analysis technique. Based on the results of research on the science literacy skills of public and private junior high school science teachers in Poasia District, Kendari City is generally in the low category with an average percentage of $56.9 \%$ with a standard deviation of $12.3 \%$. Meanwhile, his technological literacy skills are generally in the moderate category with an average percentage of $69 \%$ with a standard deviation of $9 \%$.

Keywords: Literacy; Scientific Literacy; Technological Literacy

\section{PENDAHULUAN}

Dalam upaya peningkatan mutu pendidikan, maka pada pembelajaran abad ke-21 ini terjadi perubahan paradigma belajar yaitu, dari paradigma teaching menjadi paradigma learning. Artinya bahwa sebelumnya pembelajaran hanya berpusat pada guru sedangkan saat ini pembelajaran berpusat pada peserta didik. Berdasarkan data Programe for International Student Assessment (PISA) kemampuan literasi sains peserta didik Indonesia masih dibawah rata-rata jika dibandingkan dengan rerata skor Internasional dan secara umum berada pada kategori terendah PISA (Toharudin, dkk., 2011: 19). Pembelajaran sains masih bercirikan transfer sains sebagai produk (fakta, hukum dan teori) yang harus dihafalkan sehingga aspek sains sebagai proses dan sikap benar-benar terabaikan (Istyadji, 2007: 2). Pada penelitian Suroso (2012) menyimpulkan bahwa pembelajaran tidak dikaitkan dengan konteks kehidupan nyata, pembelajaran jarang dimulai dari masalah-masalah aktual, pembelajaran sains di sekolah cenderung bertolak dari materi pelajaran, bukan dari tujuan pokok pembelajaran sains dan kebutuhan peserta didik serta tindak pembelajaran sains cenderung hanya mengantisipasi ujian.

Menurut Zakaria dan Ihsan (2007) peserta didik tidak hanya membutuhkan pengetahuan dan keterampilan motorik saja tetapi perlu dilengkapi dengan kecakapan hidup yang merupakan sarana bagi tumbuhnya keterampilan berkomunikasi dan keterampilan menyelesaikan masalah-masalah aktual dalam kehidupan sehari-hari. Faktor lain, dapat dilihat dari rendahnya minat belajar peserta didik, sarana dan prasarana yang kurang memadai, lemahnya pemahaman terhadap konten sains, proses sains dan konteks sains yang diperoleh, lemahnya kemampuan membaca dan menafsirkan data dalam bentuk gambar, tabel, diagram dan bentuk penyajian lainnya, serta kemampuan nalar ilmiah yang rendah, 
rendahnya kemampuan literasi sains dan teknologi yang dimiliki guru sebagai pendidik khususnya guru IPA. Hal tersebut merupakan salah satu faktor rendahnya literasi sains di Indonesia.

\section{METODE}

a) Jenis Penelitian

Jenis penelitian ini merupakan jenis penelitian deskriptif kuantitatif, sehingga menggunakan desain penelitian kuantitatif yaitu penelitian yang gambarannya menggunakan ukuran, jumlah atau frekuensi.

b) Subjek Penelitian

Subjek penelitian ini adalah seluruh guru IPA SMP Negeri dan Swasta se-Kecamatan Poasia yang terdiri dari SMPN 5 Kendari sebanyak 13 guru, SMPN 20 Kendari sebanyak 5 guru, dan SMP Barakati sebanyak 2 guru.

c) Waktu dan Tempat Penelitian

Penelitian ini telah dilaksanakan tanggal 20-26 Oktober 2018 pada semester ganjil tahun pelajaran 2018/2019 di SMP Negeri dan Swasta se-Kecamatan Poasia Kota Kendari Provinsi Sulawesi Tenggara.

d) Teknik Pengumpulan Data
Data dalam penelitian ini adalah data primer yang dikumpulkan dengan menggunakan soal tes dan angket. Adapun jenis data yang digunakan dalam penelitian ini adalah data kuantitatif atau data berupa angka-angka seperti jumlah guru dan hasil tes literasi sains serta kuesioner literasi teknologi yang dikuantitatifkan.

e) Teknik Analisis Data

Teknik analisis data yang digunakan untuk mengetahui kemampuan literasi sains dan literasi teknologi guru IPA, yaitu teknik analisis deskriptif yang dimaksudkan untuk memberikan gambaran tentang kemampuan literasi sains dan literasi teknologi guru-guru IPA dengan langkah - langkah yang merujuk penelitian yang dilakukan oleh Hartika, 2016. Untuk menentukan kriteria kemampuan literasi sains dan teknologi berdasarkan kategori merujuk pada Djaali dan Muljono (2008) dalam penelitian Noviana (2017)

\section{HASIL PENELITIAN}

a) Hasil Presentase Kemampuan Literasi Sains Guru IPA se-Kecamatan Poasia

Adapun hasil presentase kemampuan literasi sains Guru IPA dapat dilihat pada tabel 1.berikut:

Tabel 1 Hasil Presentase Kemampuan Literasi Sains Guru IPA se-Kecamatan Poasia

\begin{tabular}{|c|c|c|c|c|c|}
\hline \multirow{2}{*}{ No } & \multirow{2}{*}{ Nama Sekolah } & \multicolumn{3}{|c|}{$\begin{array}{c}\text { Kemampuan Literasi Sains Masing- } \\
\text { Msing Aspek }\end{array}$} & \multirow{2}{*}{$\begin{array}{c}\text { Kemampuan Literasi } \\
\text { Sains Secara Umum } \\
(\%)\end{array}$} \\
\hline & & $\begin{array}{c}\text { Konten } \\
(\%)\end{array}$ & $\begin{array}{c}\text { Proses } \\
(\%)\end{array}$ & $\begin{array}{c}\text { Konteks } \\
(\%)\end{array}$ & \\
\hline 1 & SMPN 5 Kendari & 63,5 & 51 & 49,4 & 54,6 \\
\hline 2 & SMPN 20 Kendari & 76,7 & 61,8 & 63,3 & 67,3 \\
\hline 3 & SMP Barakati & 45,8 & 40,9 & 50 & 45,6 \\
\hline
\end{tabular}

b) Hasil Presentase Kemampuan Literasi Teknologi Guru IPA se-Kecamatan Poasia
Aadapun hasil presentase kemapuan litersi teknologi masing - masing guru IPA se-Kecamatan Poasia dapat dilihat pada tabel 2.berikut:

Tabel 2. Hasil Presentase Kemampuan Literasi Sains Guru IPA Masing-Masing Sekolah seKecamatan Poasia

\begin{tabular}{|c|c|c|c|c|c|c|}
\hline \multirow{2}{*}{ No } & \multirow{2}{*}{ Nama Sekolah } & \multicolumn{4}{|c|}{$\begin{array}{c}\text { Kemampuan Literasi Teknologi Masing- } \\
\text { Msing Aspek }\end{array}$} & \multirow{2}{*}{$\begin{array}{c}\text { Kemampuan } \\
\text { Literasi Sains } \\
\text { Secara Umum } \\
(\%)\end{array}$} \\
\hline & & $\begin{array}{c}\mathrm{A} \\
(\%)\end{array}$ & $\begin{array}{c}\mathrm{B} \\
(\%)\end{array}$ & $\begin{array}{c}\mathrm{C} \\
(\%)\end{array}$ & $\begin{array}{c}\mathrm{D} \\
(\%)\end{array}$ & \\
\hline 1 & SMPN 5 Kendari & 81,5 & 78,8 & 51 & 63,5 & 68,7 \\
\hline 2 & SMPN 20 Kendari & 88 & 80 & 58 & 67,4 & 73,3 \\
\hline 3 & SMP Barakati & 60 & 67,5 & 50 & 67 & 61,1 \\
\hline
\end{tabular}


Keterangan:

A: Profil akses terhadap TIK dan internet

B: Minat dan sikap terhadap penggunaan TIK

C: Penguasaan aplikasi dan piranti lunak

D: Kompetensi teknologi digital

\section{PEMBAHASAN}

Jika ditinjau dari kemampuan literasi sains guru IPA pada masing-masing sekolah yang berada di Kecamatan Poasia yang dapat dilihat pada Tabel 4.2 yaitu SMPN 5 Kendari presentase rata-rata kemampuan literasi sains pada aspek konten $63,5 \%$ berada pada kategori cukup, aspek proses $51 \%$ berada pada kategori rendah dan aspek konteks $49,4 \%$ berada pada kategori rendah. Secara umum kemampuan literasi sains guru IPA SMPN 5 Kendari berada pada kategori rendah dengan presentase ratarata kemampuan literasi sainsnya sebesar $54,6 \%$. Kemampuan literasi sains guru IPA SMPN 20 Kendari pada aspek konten 76,7\% berada pada kategori baik, aspek proses $61,8 \%$ berada pada kategori cukup dan aspek konteks $63,3 \%$ berada pada kategori cukup. Secara umum kemampuan literasi sains guru IPA SMPN 20 Kendari berada pada kategori cukup dengan presentase rata-rata kemampuan literasi sainsnya sebesar 67,3\%. Kemampuan literasi sains guru IPA SMP Barakati pada aspek konten $45,8 \%$ berada pada kategori rendah, aspek proses $40,9 \%$ berada pada kategori sangat rendah dan aspek konteks $50 \%$ berada pada kategori rendah. Secara umum kemampuan literasi sains guru IPA SMP Barakati berada pada kategori rendah dengan presentase ratarata kemampuan literasi sainsnya sebesar $45,6 \%$.

Secara umum rata-rata persentase kemampuan literasi teknologi guru IPA seKecamatan Poasia sebesar 69\% atau dalam kategori cukup dengan standar deviasinya 9\%, Dari 20 guru IPA yang menjadi objek penelitian hanya 1 orang berada pada kategori sangat baik, 6 orang berada pada kategori baik, 11 orang berada pada kategori cukup dan 2 orang berada pada kategori rendah. Secara umum kemampuan literasi teknologi guru IPA seKecamatan Poasia Jika ditinjau dari kemampuan literasi teknologi guru IPA pada masing-masing sekolah yang berada di Kecamatan Poasia yaitu SMPN 5 Kendari presentase rata-rata kemampuan literasi teknologi pada aspek profil akses terhadap TIK dan internet sebesar $81,5 \%$ berada pada kategori baik, aspek minat dan sikap terhadap penggunaan TIK $78,8 \%$ berada pada kategori baik, aspek penguasaan aplikasi dan piranti lunak $51 \%$ berada pada kategori rendah dan aspek kompetensi digital 63,5\% berada pada kategori cukup. Secara umum kemampuan literasi teknologi guru IPA SMPN 5 Kendari berada pada kategori cukup dengan presentase rata-rata kemampuan literasi teknologinya sebesar 68,7\%. Kemampuan literasi teknologi guru IPA SMPN 20 Kendari pada aspek profil akses terhadap TIK dan internet sebesar $88 \%$ berada pada kategori sangat baik, aspek minat dan sikap terhadap penggunaan TIK $80 \%$ berada pada kategori baik, aspek penguasaan aplikasi dan piranti lunak $58 \%$ berada pada kategori cukup dan aspek kompetensi digital $67,4 \%$ berada pada kategori cukup. Secara umum kemampuan literasi teknologi guru IPA SMPN 20 Kendari berada pada kategori baik dengan presentase rata-rata kemampuan literasi teknologinya sebesar 73,3\%. Kemampuan literasi teknologi guru IPA SMP Barakati pada aspek profil akses terhadap TIK dan internet sebesar $60 \%$ berada pada kategori cukup, aspek minat dan sikap terhadap penggunaan TIK $67,5 \%$ berada pada kategori cukup, aspek penguasaan aplikasi dan piranti lunak $50 \%$ berada pada kategori rendah dan aspek kompetensi digital $66 \%$ berada pada kategori cukup. Secara umum kemampuan literasi teknologi guru IPA SMP Barakati berada pada kategori cukup dengan presentase rata-rata kemampuan literasi teknologinya sebesar $61,1 \%$.

\section{KESIMPULAN}

Kemampuan literasi sains guru IPA SMP Negeri dan Swasta se-Kecamatan Poasia, Kota Kendari secara umum berada pada kategori rendah dengan presentase rata-rata sebesar 56,9\% dengan standard deviasi 12,3\%. Dan Kemampuan kliterasi teknologi guru IPA SMP Negeri dan Swasta se-Kecamatan 
Poasia, Kota Kendari secara umum berada pada kategori cukup dengan presentase rata-rata sebesar $69 \%$ dengan standard deviasi $9 \%$.

\section{DAFTAR PUSTAKA}

Arikunto, S. 2009. Prosedur Penelitian Suatu Pendekatan Praktik. Rineka Cipta. Jakarta.

Hartika, D. 2016. Profil Kompetensi Literasi Sains Siswa Berdasarkan The Programme For International Student Assesment (PISA) Pada Konten Biologi (Kuasi Deskriptif Siswa Kelas IX SMP Se-Kecamatan Teluk Betung Utara Di Bandar Lampung). Fakultas Keguruan dan Ilmu Pendidikan Universitas Lampung. Bandar Lampung.

Istyadji, M. 2007. Penerapan Paduan Model Pembelajaran Siklus belajar dengan Kooperatif GI Untuk Meningkatkan Kualitas Proses dan hasil Belajar Siswa SMA. PPS Universitas Negeri Malang. Jawa Timur.
Noviana, M dan Jullianto, T. 2017. Profil Kemampuan Literasi Sains Siswa SMP di Kota Purwokerto Ditinjau dari Aspek Konten, Proses dan Konteks Sains. Universitas Muhamadiyah Purwokerto. Vol. 1, No. 2, September 2017

Suroso. 2012. Penerapan Model Pembelajaran Kontekstual dalam Meningkatkan Keterampilan Proses dan Hasil Belajar Sains Siswa Kelas V SD No 5 Bandung. Skripsi. UPI. Bandung.

Toharudin, U., Hendrawati, S. dan Rustaman, A. 2011. Membangun literasi sains peserta didik. Humaniora. Bandung.

Zakaria, E. dan Ihsan, Z. 2007. Promoting Cooperative Learning in Science and Mathematics Education: A Malaysian Perspective. Eurasia Journal of Mathematics, Scince \& Technology Education. Dilihat 23 Oktober 2008. (http:/ /www. ejmste.com). 